\title{
Intestinal helminths of spiny mice (Acomys cahirinus dimidiatus) from St Katherine's Protectorate in the Sinai, Egypt
}

\author{
J.M. Behnke ${ }^{1 *}$, C.J. Barnard ${ }^{1}$, N. Mason ${ }^{1}$, P.D. Harris ${ }^{1}$, \\ N.E. Sherif ${ }^{2}$, S. Zalat ${ }^{2}$ and F.S. Gilbert ${ }^{1}$ \\ ${ }^{1}$ School of Biological Sciences, University Park, University of \\ Nottingham, Nottingham, NG7 2RD, UK: ${ }^{2}$ Department of Zoology, \\ Faculty of Science, Suez Canal University, Ismailia, Egypt
}

\begin{abstract}
Spiny mice, Acomys cahirinus dimidiatus, inhabiting the wadis close to St Katherine in the mountains of the Sinai peninsula, were trapped and their helminth parasites were studied. Sixty one mice provided faeces for analysis and 27 were killed and autopsied. Six species of helminths were recorded (the spirurid nematodes, Protospirura muricola (74.1\%) and Mastophorus muris (11.1\%), the oxyuroid nematodes, Dentostomella kuntzi (59.3\%), Aspiculuris africana (3.7\%), and Syphacia minuta (3.7\%) and the hymenolepidid cestode Rodentolepis negevi $(18.5 \%))$. The spirurids were the dominant species present, accounting for up to $0.87 \%$ of total host body weight. Analysis of worm weights and lengths suggested that transmission had been taking place in the months preceding our study. No sex difference in the prevalence or abundance of spirurids was detected. Significant differences were identified in the abundance of total nematode burdens and the mean helminth species richness between the three wadis which provided multiple captures of mice. There was also a marked effect of host age on both parameters. A highly significant positive correlation between spirurid egg counts and total worm biomass indicated that non-invasive techniques based on egg counts could be used to quantify worm burdens and when this technique was applied to a larger sample size $(n=61)$, a significant difference between sites but no host sex or age effects were detected for spirurid faecal egg counts. The data suggest that there are differences between helminth component communities infecting spiny mice in different neighbouring wadis, a hypothesis which will be explored further through our continuing studies in the Sinai.
\end{abstract}

\section{Introduction}

The ecology, and particularly the component community structure, of helminth parasites in small rodent populations has been well documented in temperate regions of Europe (Kisielewska, 1970; Haukisalmi et al., 1988; Montgomery \& Montgomery, 1990; Abu-Madi et al., 1998) and northern America (Murphy, 1952; Grundman, 1957;

*Fax: 01159513252

E-mail: jerzy.behnke@nottingham.ac.uk
Boggs et al., 1991). In contrast, and despite the wealth of information on species lists and taxonomy (Myers et al., 1962), there is little comparable data for rodents living in the tropics (Ow-Yang, 1971). In particular, ecological studies on the parasites of rodents inhabiting hostile, arid regions in the Middle East and Africa are scarce (Greenberg, 1969; Erhardova-Kotrla \& Daniel, 1970; Wertheim \& Greenberg, 1970) and little is known about the relative importance of factors responsible for variation in the helminth infracommunity structures of small rodents inhabiting these regions. 
The recently established St Katherine's Protectorate in the Sinai Mountains of Egypt is a unique habitat, comprising an extensive and complex system of dry valleys (wadis) (Hobbs, 1995). It is known to be the most biologically diverse region of all Egypt, with a very high proportion of Egypt's fauna and flora (e.g. 2/3 of all the butterflies), including many endemics (44\% of Egypt's endemic flora). The Park is currently being documented and studied at a variety of levels, with an ultimate goal of formulating specific management plans to preserve this habitat (Zalat \& Gilbert, 1998). Projects include basic biodiversity studies to establish population and community structures within the wadi system (Willmer et al., 1994; Gilbert et al., 1996) and the impact on these of encroaching human settlement and pastoral activities. Studies have focused particularly on the effects of grazing on coevolved plant and insect pollination communities and, more recently, on the effects of increasing commensalism of rodent communities and rodent-borne parasites.

Little is known about the diseases of wild animals in the region, but, as part of the documentation of the wild life in the Park, rodents were trapped and identified, creating an opportunity for the assessment of their parasite burdens. We report here the results of our preliminary investigations into the diversity of parasitic helminths of the most common desert rodent in the region, the Egyptian spiny mouse Acomys cahirinus dimidiatus. Our second objective was to assess whether the helminth component community structures of small rodent populations living in five disparate wadis differed, particularly with respect to the dominant parasite species. Because of the fragile nature of the local habitats and in order to enable long-term studies to be initiated, it was important to establish for the future whether helminth burdens could be monitored reliably by non-invasive methods. If successful, this would enable subsequent projects to minimize the numbers of animals killed for research purposes. Our third objective was therefore to evaluate faecal analysis as a method for quantifying infections of the dominant helminths, the spirurid nematodes Protospirura muricola and Mastophorus muris.

\section{Materials and methods}

\section{The study sites}

The study was conducted during a two week period in May-June 1997 and was based at the Environmental Research Centre of Suez Canal University, located on the periphery of the town of St Katherine, Central Sinai, Egypt. All trapping was carried out close to St Katherine, in the surrounding wadis. The environment has been described by Hobbs (1995) and Zalat \& Gilbert (1998). Wadi El Arbain (called Wadi El Lega until 1979) and Wadi Tofaha radiate from the town of St Katherine, and are fully described in Willmer et al. (1994) and Gilbert et al. (1996). Wadi Abu Seylah is part of the Plain of El Raha and is currently the site of the town's refuse dump. Wadi Gebal is a system of wadis separated from St Katherine by a ridge of mountains, and is well known as a popular destination for trekkers (fully described in Zalat \& Gilbert, 1998). A feature of the wadis of the high mountains is the many walled Bedouin gardens, built around sources of water, and acting as foci for the fauna and flora (Hobbs, 1995). Trapping usually took place in or near such gardens, which can be considered as semi-isolated vegetated patches in the landscape. Wadi Sheikh is a wide flat wadi running towards the Oasis of Feiran from St Katherine, bearing the road to Feiran and the Suez Gulf.

\section{Rodents}

Rodents were caught in Sherman traps placed among the rocks and boulders in the wadi bases and partially up the lower slopes. Traps were set out at dusk and inspected in the early morning soon after sunrise when captured animals were removed. The traps were then closed and reset in the evening. All animals were inspected in the field. Each was identified, sexed, weighed, measured, scrutinized for any evident lesions, then fur-marked to enable identification on recapture and either released near to the point of capture or brought back to the centre for autopsy. Animals were trapped on several nights in three of the sites but in the case of Wadi Gebal and Wadi Sheikh for no more than a single night because of the distance from the field centre. Faecal samples were taken from the traps and placed immediately into modified SAF fluid $(9 \mathrm{~g}$ anhydrous sodium acetate, $20 \mathrm{ml}$ glacial acetic

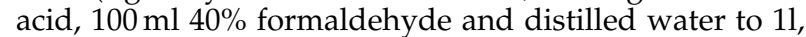
with $\mathrm{pH}=4.15$ ) in $1.5 \mathrm{ml}$ plastic tubes, for subsequent transport to Nottingham.

\section{Worm recovery}

Animals for autopsy were brought back to the field centre, and killed usually within 24 h of capture. Each was again carefully inspected for ectoparasites and any evident lesions. The entire intestinal tract was removed, the stomach was examined immediately after its removal and worms were counted, collected into labelled, air-tight tubes and preserved in $70 \%$ ethanol for subsequent examination. Some of the small intestines were also examined on the same day, but in most cases the whole of the remaining intestinal tract (small intestine, caecum and colon) was placed into $10 \%$ formalin and conveyed to Nottingham for subsequent examination. All of these preserved intestines were carefully examined in FebruaryMarch 1998, 9-10 months after the expedition. Worms were removed and transferred to $70 \%$ ethanol.

\section{Identification of worms}

Nematodes were removed from $70 \%$ ethanol and cleared in lactoglycerol on glass slides immediately before examination by light microscopy. Relevant measurements were recorded through a calibrated eyepiece graticule and the data were compared with published species descriptions. In some cases, scanning electron microscopy was used to differentiate between species, particularly in the case of Protospirura muricola and Mastophorus muris. Specimens for scanning electron microscopy were dehydrated stepwise to $100 \%$ ethanol, critical point dried, mounted with the anterior end facing upwards on metal stubs with silver adhesive, sputter coated with gold (Polaron E5100), and examined with a Joel 840 scanning electron microscope at $15 \mathrm{kV}$. 


\section{Worm biomass and length}

Each intact worm was individually weighed on an electronic top-pan balance reading to the nearest $0.1 \mathrm{mg}$. The worms were removed from $70 \%$ ethanol, blotted with tissue paper to absorb surface alcohol and then placed on the balance. Readings were taken exactly $20 \mathrm{~s}$ after removal from the tube. All nematodes were drawn to scale under appropriate magnification using a camera lucida. Line drawings were then converted into units of length by using a digitizer pad and an IBM computer with a programme for conversion of lengths traced into metric units. Each drawing was measured three times and the mean value used. All intact worms were measured.

\section{Egg counts}

It was not possible to analyse faecal samples at the field centre, so all specimens were carefully examined in the period November 1997 to February 1998 in Nottingham. The material in each tube was broken down by careful stirring with a sharp seeker, until no large clumps remained. Each tube was then centrifuged at $1000 \mathrm{rpm}$ for $10 \mathrm{~min}$. The height of the deposit was measured and converted to volume by comparison with calibrated tubes. The total volume was adjusted to no more than $1 \mathrm{ml}$. In turn, the contents of each tube were resuspended with the aid of a standard laboratory bench rotamixer and a $10 \mu \mathrm{l}$ aliquot was removed, transferred to a glass slide, covered with a cover slip and examined under the microscope. All eggs observed in each specimen were identified by morphology, measured, photographed and each type was counted separately. Four samples were examined from each tube, and all specimens which failed to show any eggs were re-examined four more times. Egg counts were then expressed as eggs per $\mathrm{ml}$ of faecal deposit.

\section{Statistical analysis}

Summary statistics are presented as mean abundance (including all uninfected animals) \pm standard error of the mean (S.E.M.). However, following multifactorial ANOVA, we also present fitted (least squares) means for factors showing significant effects.

Prevalence is given as the percentage of animals carrying a specific parasite taxon or taxa and was analysed by maximum likelihood techniques based on log linear analysis of contingency tables, implemented by the software package, Statgraphics Version 7. Beginning with the most complex model, involving all possible main effects and interactions, those combinations which did not contribute significantly to explaining variation in the data were eliminated stepwise beginning with the least significant. A minimum sufficient model was then obtained, for which the likelihood ratio of $\chi^{2}$ squared was not significant, indicating that the model was sufficient in explaining the data.

Parametric statistics (multifactorial ANOVA, Statgraphics Version 7) were used for analysis of worm burdens, where data (sometimes suitably transformed) met the required assumptions, otherwise non-parametric tests were employed. The negative binomial exponent $k$ was estimated using the maximum likelihood procedure of Elliott (1977). The goodness of fit to the negative binomial distribution was tested by $\chi^{2}$.

\section{Results \\ Numbers of mice examined}

The number of $A$. cahirinus dimidiatus caught at each site and examined by faecal analysis and by autopsy is shown in table 1. In total, 61 mice (28 males and 33 females) were caught and provided faeces for analysis. Of these, 27 (15 males and 12 females) were killed and autopsied.

\section{Helminth species}

Six species of helminths were recovered from the autopsied animals (table 2 ) and $96.3 \%$ harboured at least one species. The majority of mice carried two helminth species, (fig. 1) and the mean species richness (no. of helminth species per mouse) was $1.7 \pm 0.1$, with a slightly,

Table 1. Number of Acomys cahirinus dimidiatus examined by faecal analysis and by autopsy in relation to host sex, age and site of capture.

\begin{tabular}{lllcc}
\hline Site & Sex & Age & Autopsy & Faecal analysis \\
\hline Wadi El-Arbain & Male & Adult & 5 & 14 \\
& Female & Adult & 5 & 13 \\
Wadi Tofaha & Male & Juvenile & 3 & 4 \\
& Male & Adult & 2 & 5 \\
& Female & Juvenile & 0 & 3 \\
\multirow{2}{*}{ Wadi Abu Seylah } & Female & Adult & 2 & 12 \\
& Male & Juvenile & 1 & 1 \\
& Male & Adult & 3 & 3 \\
Wadi Sheikh & Female & Adult & 4 & 4 \\
Wadi Gebal & Male & Adult & 1 & 1 \\
Total & Female & Adult & 1 & 1 \\
\hline
\end{tabular}


Table 2. The prevalence and abundance of intestinal helminths in Acomys cahirinus dimidiatus, from St Katherine's Protectorate in the Sinai, Egypt.

\begin{tabular}{|c|c|c|c|c|c|c|}
\hline \multirow{2}{*}{$\begin{array}{l}\text { Species of } \\
\text { parasites }\end{array}$} & \multirow[b]{2}{*}{ Sex of host } & \multirow[b]{2}{*}{ Prevalence } & \multicolumn{4}{|c|}{ Abundance } \\
\hline & & & Mear & E.M. & Median & Range \\
\hline \multirow[t]{3}{*}{ Protospirura muricola } & Male mice & 66.7 & 4.7 & 1.3 & 3 & $0-15$ \\
\hline & Female mice & 83.3 & 7.3 & 2.4 & 4 & $0-27$ \\
\hline & Sexes combined & 74.1 & 5.9 & 1.3 & 3 & $0-27$ \\
\hline \multirow[t]{3}{*}{ Mastophorus muris } & Male mice & 6.7 & 0.2 & 0.2 & 0 & $0-3$ \\
\hline & Female mice & 16.7 & 1.8 & 1.4 & 0 & $0-17$ \\
\hline & Sexes combined & 11.1 & 0.9 & 0.6 & 0 & $0-17$ \\
\hline \multirow{3}{*}{ Dentostomella kuntzi } & Male mice & 53.3 & 2.8 & 1.1 & 1 & $0-12$ \\
\hline & Female mice & 66.7 & 3.1 & 0.8 & 2 & $0-7$ \\
\hline & Sexes combined & 59.3 & 2.9 & 0.7 & 1 & $0-12$ \\
\hline \multirow[t]{3}{*}{ Aspiculuris africana } & Male mice & 6.7 & 1.5 & 1.5 & 0 & $0-22$ \\
\hline & Female mice & 0 & 0 & 0 & 0 & 0 \\
\hline & Sexes combined & 3.7 & 0.8 & 0.8 & 0 & $0-22$ \\
\hline \multirow[t]{3}{*}{ Syphacia minuta } & Male mice & 0 & 0 & 0 & 0 & 0 \\
\hline & Female mice & 8.3 & 6.4 & 6.4 & 0 & $0-77$ \\
\hline & Sexes combined & 3.7 & 2.9 & 2.9 & 0 & $0-77$ \\
\hline \multirow[t]{3}{*}{ Rodentolepis negevi } & Male mice & 20.0 & 0.7 & 0.5 & 0 & $0-8$ \\
\hline & Female mice & 16.7 & 1.0 & 0.7 & 0 & $0-7$ \\
\hline & Sexes combined & 18.5 & 0.8 & 0.4 & 0 & $0-8$ \\
\hline \multirow[t]{3}{*}{ Nematoda combined } & Male mice & 86.7 & 9.2 & 2.7 & 6 & $0-38$ \\
\hline & Female mice & 100.0 & 18.5 & 6.2 & 13 & $2-81$ \\
\hline & Sexes combined & 92.6 & 13.4 & 3.2 & 10 & $0-81$ \\
\hline
\end{tabular}

although not significantly, higher mean among female compared with male mice (females $=1.92 \pm 0.15$, males $=$ $1.53 \pm 0.19$; Kruskal-Wallis test $H=2.265, P=\mathrm{NS}$ ).

Spirurid nematodes were common in the stomachs of the mice. Protospirura muricola Geodelst, 1916 was the dominant species occurring at four of the five sites studied, but Mastophorus muris (Gmelin, 1790= Protospirura muris) was also present in three of the autopsied animals, one from each of Wadi Gebal, El Arbain and Tofaha (table 3 ). The two species could not be reliably distinguished on morphological grounds when the head of the worm had been damaged during processing, and no attempt was made to differentiate spirurid larvae. Hence, in some of the analyses which follow, the two species are treated as part of a single taxon. Collectively, the spirurids were present in $85.2 \%$ of the mice $(73.3 \%$ of males and $100 \%$ of females).

Three species of oxyuroids were identified but only one, Dentostomella kuntzi Myers, 1961 (Heteroxynematidae) was widespread infecting $59.3 \%$ of the animals, although this species was relatively rare in Wadi El Arbain in comparison with other sites. Syphacia minuta Greenberg, 1969 (Oxyuridae) was found in one animal from Wadi Gebal, while Aspiculuris africana Quentin, 1966 (Heteroxynematidae) was found in a single mouse from Wadi Abu Seylah.

Four mice carried hymenolepidid tapeworms. Two individuals contained only scoleces, but the remaining two mice were infected with gravid worms which conformed to the description of Rodentolepis negevi Greenberg, 1969

Table 3. Mean parasite abundance by site of capture.

\begin{tabular}{|c|c|c|c|c|c|c|}
\hline \multirow[b]{2}{*}{ Site } & \multicolumn{4}{|c|}{$\begin{array}{l}\text { Mean worm burden of parasite taxon }{ }^{1} \\
\qquad( \pm \text { S.E.M.) }\end{array}$} & \multicolumn{2}{|c|}{$\begin{array}{l}\text { Mean no. of species }{ }^{1} \\
\quad( \pm \text { S.E.M.) }\end{array}$} \\
\hline & Spirurids & D. kuntzi & All Nematoda & Cestoda & Nematoda & Helminths \\
\hline Wadi El-Arbain & $6.4 \pm 1.84$ & $0.9 \pm 0.71$ & $7.3 \pm 1.86$ & $1.7 \pm 0.98$ & $1.1 \pm 0.18$ & $1.5 \pm 0.17$ \\
\hline Wadi Tofaha & $4.1 \pm 2.25$ & $3.3 \pm 1.44$ & $7.4 \pm 3.08$ & $0.7 \pm 0.7$ & $1.4 \pm 0.30$ & $1.6 \pm 0.37$ \\
\hline Wadi Abu Seylah & $9.3 \pm 3.09$ & $5.8 \pm 1.46$ & $17.8 \pm 4.67$ & 0 & $2.0 \pm 0.19$ & $2.0 \pm 0.19$ \\
\hline Wadi Sheikh & 12 & 1 & 13 & 0 & 2 & 2 \\
\hline Wadi Gebal & 4 & 0 & 81 & 0 & 2 & 2 \\
\hline
\end{tabular}

\footnotetext{
${ }^{1}$ Arthimetic means of parasite abundance based on all the animals autopsied (including the uninfected mice) at each
} site. 


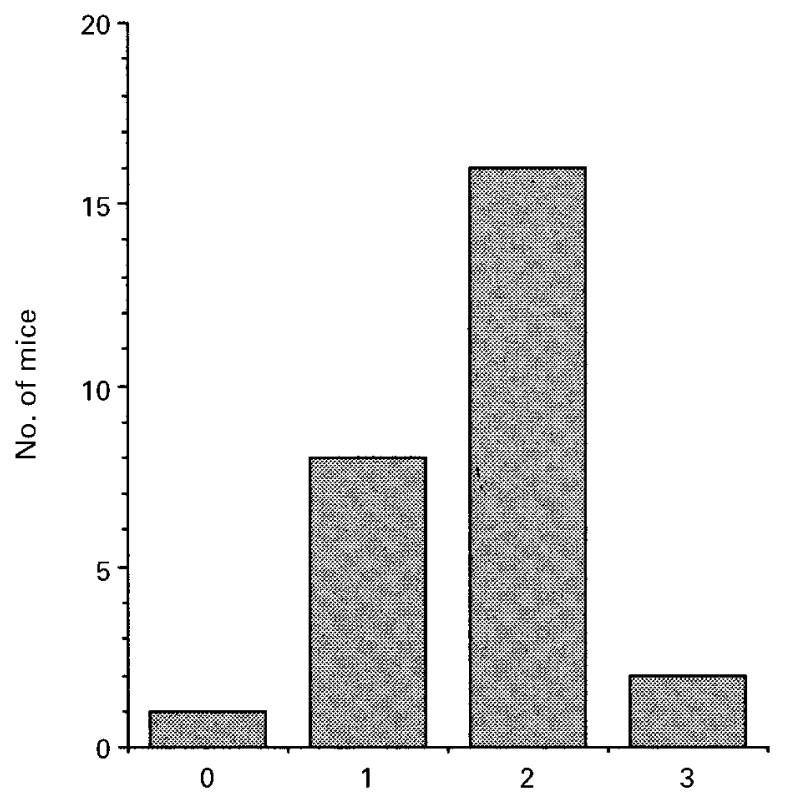

No. of helminth species harboured

Fig. 1. Frequency distribution of number of helminth species harboured by the mice which were autopsied $(n=27)$.

(Hymenolepididae Ariola, 1899). This species was found only in Wadi El Arbain and Wadi Tofaha.

\section{Frequency distribution of the spirurid nematodes and D. kuntzi}

The distribution of both of the spirurid nematodes and D. kuntzi, in the host population, conformed to the negative binomial distribution as illustrated in fig. 2 .

\section{Effect of site of capture on nematode abundance and helminth species richness}

Statistical analysis was limited to the three sites which yielded multiplecaptures:WadiElArbain,WadiTofahaand WadiAbuSeylah.Multifactorialanalysisofvarianceforthese three sites, taking age, sex and body weight into account, showed a significant main effect of site on total nematode burden $\left(F_{2,19}=4.075, P=0.034\right)$, withabundanceofnematodes increasingfromWadiElArbain,throughWadiTofahatoWadi AbuSeylah(fig.3A).Asimilarresultwasfoundfortheeffectof siteonmeanspeciesrichness(fig. $3 C ; F_{2,19}=5.373, P=0.014$ ). No significanteffectofsiteemergedforanyotheroverallmeasure of parasite burden. Therefore, mice from Wadi Abu Seylah showed a higher abundance of nematodes and had more species of helminths per individual than those from WadiEl Arbain,withWadiTofahashowingsimilarspeciesrichnessto the former and an intermediate level for abundance of nematodes.

Dentostomella kuntzi was relatively rare in Wadi El Arbain compared with the other sites (table 3) and multifactorial analysis of variance for the three sites yielding multiple captures, taking age, sex and body weight into account, confirmed that there was a significant main

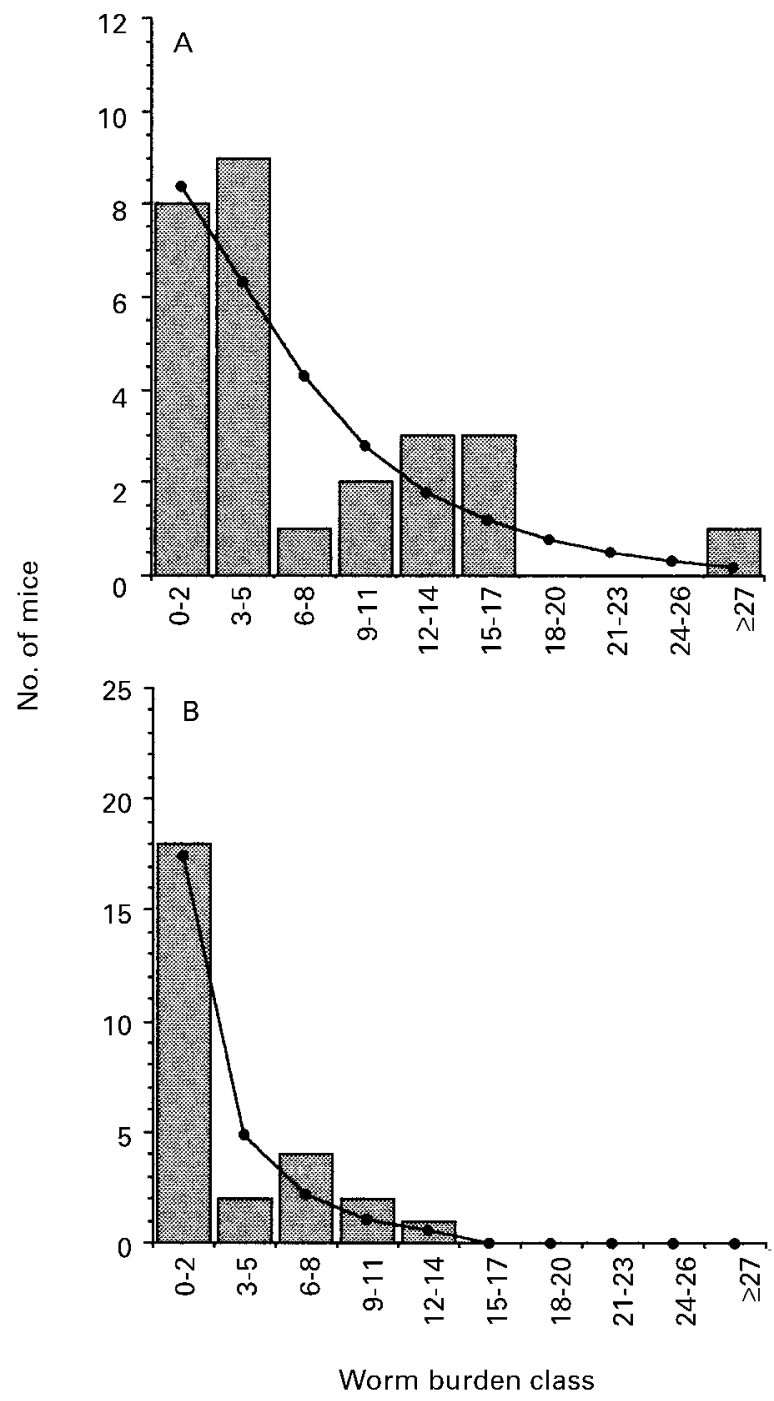

Fig. 2. Frequency distribution of spirurid nematodes (A) and Dentostomella kuntzi (B) in Acomys cahirinus dimidiatus $(n=27)$. Columns illustrate the observed data and the line graph shows the fitted negative binomial distribution. For A, $k=1.197 \pm 0.620$ $\left(\chi^{2}=1.51\right.$, dof $\left.=2, P=0.216\right)$; for $\mathrm{B}, k=0.456 \pm 0.304 \quad\left(\chi^{2}=0.02\right.$, $\operatorname{dof}=1, P=0.870)$.

effect of site on D. kuntzi worm burdens $\left(\log _{10}(x+1)\right.$ transformed) worm burdens, $\left.F_{2,19}=12.976, P=0.0003\right)$ : worm burdens increased from El Arbain, through Wadi Tofaha to Wadi Abu Seylah. No difference emerged from analysis of the spirurid nematodes by site of capture.

\section{Effect of host age on nematode abundance and helminth species richness}

Multifactorial analysis of variance for the two age categories (mature versus juvenile) across the three wadis yielding multiple captures, taking site of capture, sex and body weight into account, revealed a significant main effect of age on abundance of nematodes $\left(F_{1,19}=4.823, P=\right.$ 0.041 ; abundance of nematodes increased with age, fig. $3 \mathrm{~B}$ ). A similar, but considerably more marked effect was found 

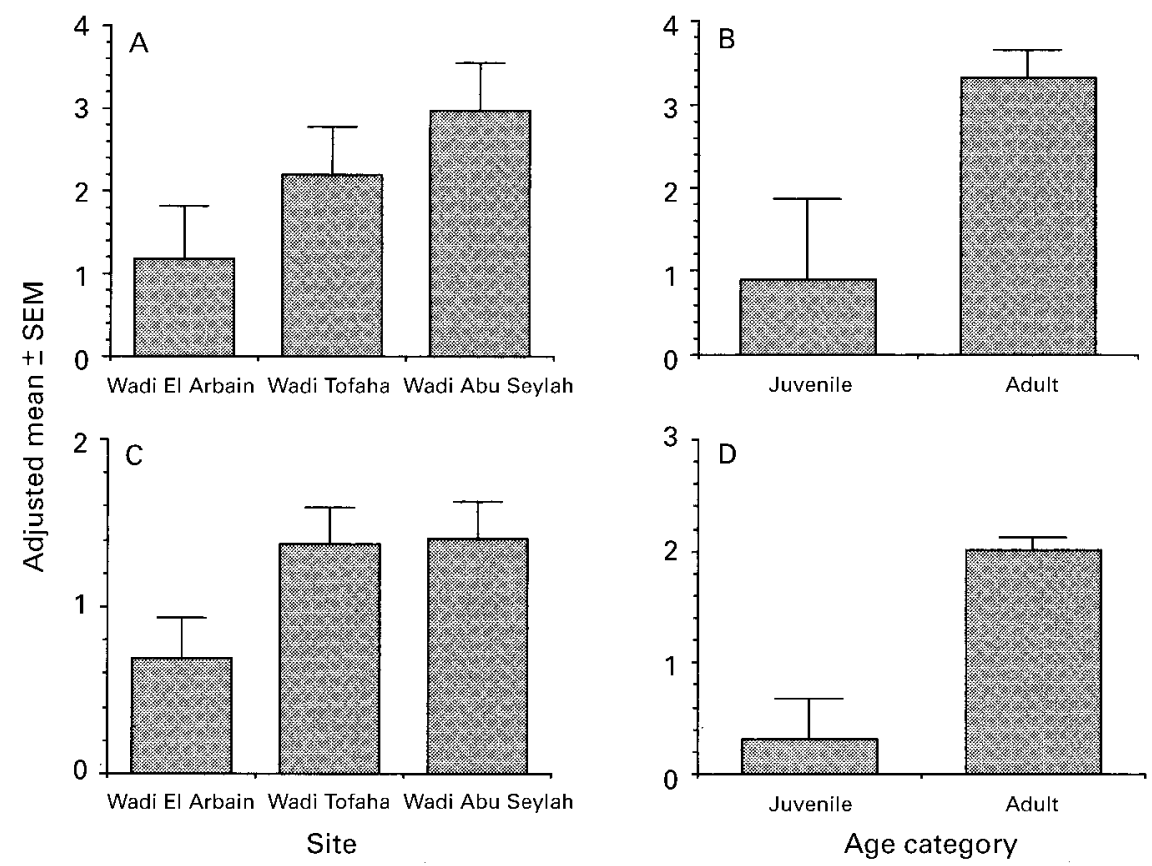

Fig. 3. Variation in abundance of nematode infections (A and B) and helminth species richness (C and D) between sites of capture (A and C) and in relation to host age (B and D). The figure shows adjusted means as fitted by a 3-way ANOVA (site + sex + age) with weight as a covariate on (A and B) total nematode burdens (square root transformed data) and (C and D) number of helminth species per mouse (not transformed data). For full statistical analysis see text.

for the effect of age on mean species richness (fig. 3D; $F_{1,19}$ $=16.537, P=0.0007)$. There was no significant effect of host age on any other measure of parasite burden.

\section{The effect of other host factors on helminth abundance and species richness}

No effect of host sex was detected on any of the measures of parasite abundance nor on helminth species richness. There was no significant independent effect of body weight, when site of capture, sex and age were taken into account.

\section{Sex ratio of the spirurid nematodes and $\mathrm{D}$. kuntzi}

A total of 183 spirurid nematodes were removed from the 23 infected mice giving a mean worm burden of 8.0 for infected animals. Forty seven worms could not be sexed and were designated as immature larvae (L3, and probably mostly L4s), 50 were males and 86 females. The male/female ratio of spirurid worms was therefore 0.58 with $36.7 \%$ of the adult worm population represented by males. The three mice which carried M. muris appeared to have just this species and no $P$. muricola. The sex ratio was 0.57 with $36.4 \%$ male worms and for

Table 4. The prevalence of infection with spirurid nematodes in Acomys cahirinus dimidiatus as detected by faecal analysis, in relation to host sex, age and site of capture.

\begin{tabular}{lllccc}
\hline Site & Sex & Age & $\begin{array}{c}\text { No } \\
\text { +ve }\end{array}$ & $\begin{array}{c}\text { Total } \\
\text { examined }\end{array}$ & $\begin{array}{c}\text { Prevalence } \\
\text { in adult mice }\end{array}$ \\
\hline Wadi El Arbain & Male & Adult & 8 & 14 & 51.9 \\
Wadi Tofaha & Female & Adult & 6 & 13 & \\
& Male & Juvenile & 0 & 4 & \\
& Male & Adult & 1 & 5 & 17.6 \\
Wadi Abu Seylah & Female & Juvenile & 0 & 3 & \\
& Female & Adult & 2 & 12 & 71.4 \\
\multirow{2}{*}{ Wadi Sheikh } & Male & Juvenile & 0 & 1 & \\
Wadi Gebal & Male & Adult & 2 & 3 & \\
Total & Male & Adult & 3 & 4 & \\
\hline
\end{tabular}




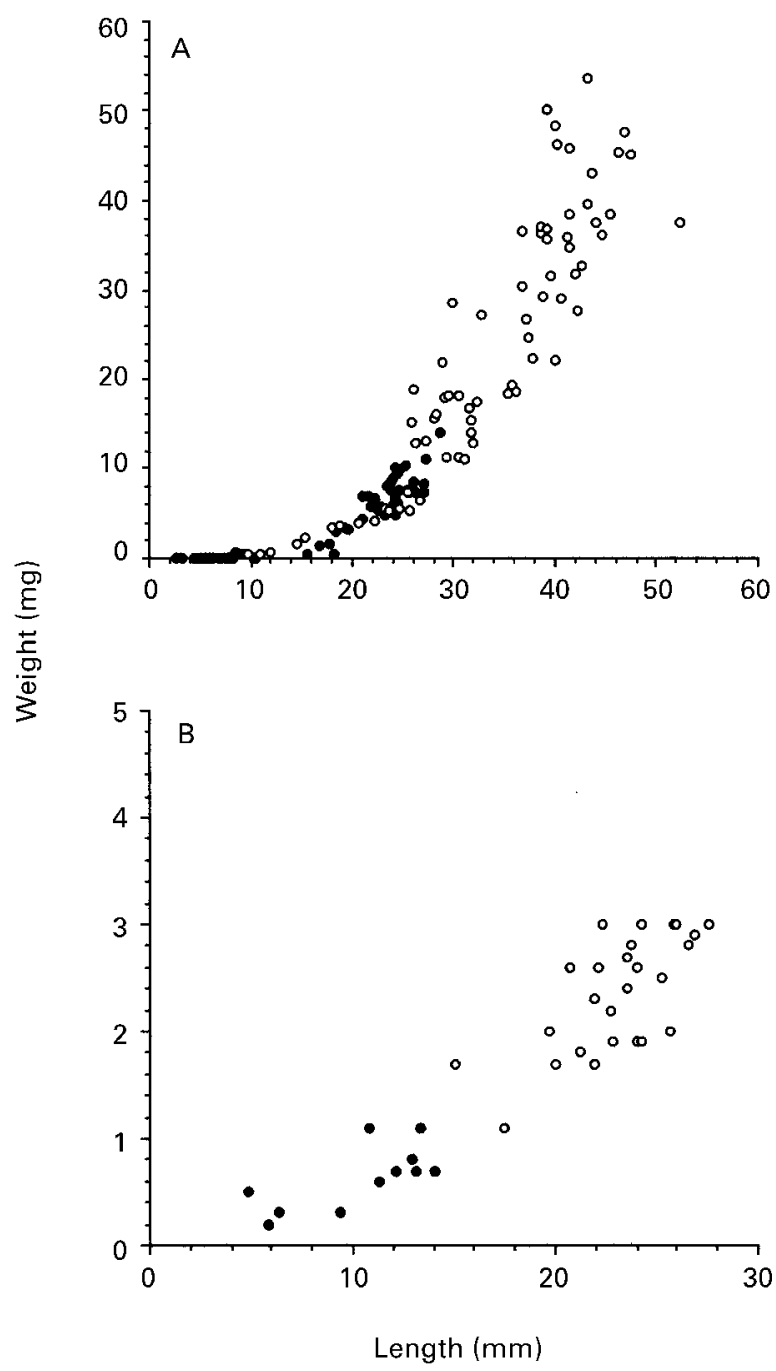

Fig. 4. Weight for length relationship of (A) the spirurid nematodes (Mastophorus muris and Protospirura muricola, combined) and (B) Dentostomella kuntzi. Mastophorus muris and P. muricola were combined because they could not be accurately separated in many specimens, especially the larval worms. The vast majority of worms which were confidently speciated were P. muricola. See text for full details. @, Male worms; $\bigcirc$, female worms.

P. muricola, separately, the values were 0.58 and $36.8 \%$, respectively.

Sixteen mice yielded a total of $79 D$. kuntzi with a mean worm burden among infected animals of 4.9 worms. Eleven worms were male and 30 female giving a male/ female ratio of 0.37 and males representing $26.8 \%$ of the adult population.

\section{Weight/length of the spirurid nematodes and $\mathrm{D}$. kuntzi}

The lengths of 161 spirurid worms (43 larvae, 47 males and 71 female worms) were measured, the remaining worms being incomplete or punctured. Forty eight males and 76 females were also weighed. Most of the larvae were too small to weigh $(<0.1 \mathrm{mg})$. Eleven male and 26 female D. kuntzi were also measured and weighed. The relationships between length and weight of these worms are illustrated in fig. 4 and frequency distributions of length and weight are presented in fig. 5.

In this sample of mice, male spirurids rarely grew to a length in excess of $28 \mathrm{~mm}$ although, at $50 \mathrm{~mm}$, female worms achieved a length almost twice as long. The maximum weight for males was $14.1 \mathrm{mg}$ and for females $28.7 \mathrm{mg}$. Dentostomella kuntzi was a shorter, and considerably lighter nematode with a maximum length of $13.34 \mathrm{~mm}$ for males and $27.5 \mathrm{~mm}$ for females and maximum weights of $1.1 \mathrm{mg}$ and $3 \mathrm{mg}$, respectively.

The spirurids, therefore, achieved a considerably greater biomass in the mice, and this is clearly shown in fig. 6 where the frequency distribution of the biomass of each of these taxa in the 27 autopsied animals is compared. One female mouse from Wadi El Tofaha carried a spirurid biomass (probably mostly M. muris) of $392.2 \mathrm{mg}$, representing $0.87 \%$ of its total body weight. The same animal had a $D$. kuntzi biomass of $4.6 \mathrm{mg}$. The highest value for mice carrying only P. muricola was $297.6 \mathrm{mg}$, representing $0.47 \%$ of total body weight.

\section{Relationship between faecal egg counts and worm burden}

The eggs of the spirurid worms were easily differentiated from the other species, but not from each other, and could be reliably quantified in faecal specimens only as spirurid eggs. Reassuringly, there were no false positives, but there were several false negatives. Of the 27 mice examined, eight had worms without detectable eggs in their faeces. Three of these had no female worms, but the remaining five did, and one had seven adult female worms.

We examined the relationship between eggs per $\mathrm{ml}$ of faeces (EPM) and various measures of parasite burden including total number of worms, number of female worms, number of male worms, total biomass, female worm biomass, etc. Stepwise partial regression analysis incorporating the total spirurid worm burden, length and weight of male and female worms and host body size (nose to anal length) as independent variables showed that EPM was predicted mainly by the total biomass of worms $\left(t_{23}=11.78, P<0.01\right)$ with no other variables entering the equation (fig. 7).

Although the eggs of D. kuntzi were distinct enough for us to be certain about their identity, they were infrequently encountered. Of the 16 animals carrying this species, eggs were only detected in two, so no further analysis was possible. As in the case of the spirurids and $D$. kuntzi, the eggs of A. africana were distinct. Tapeworm eggs were treated collectively, although among the limited material available for examination the only species present was $R$. negevi.

\section{Analysis of helminth burdens by faecal egg counts}

As table 1 shows, faecal samples were examined from sixty one mice in total. The eggs of D. kuntzi were identified in only four mice (6.6\%), those of A. africana in only one $(1.6 \%)$ and cestode eggs in only five $(8.2 \%)$ mice, limiting the scope for any further analysis of these species. 

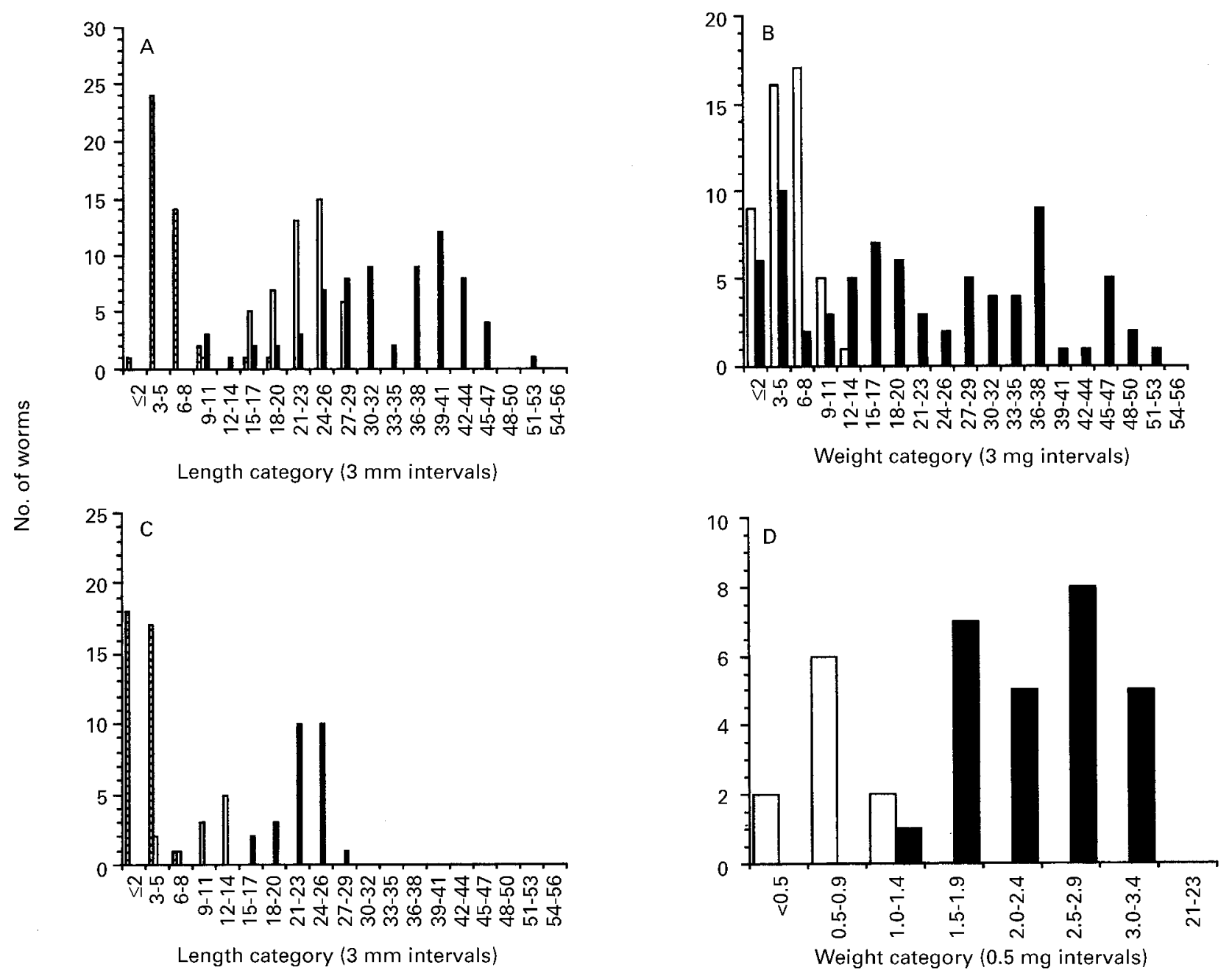

Fig. 5. Frequency distribution of the length (A and C) and weight (B and D) of larval, male and female spirurid nematodes (A and B) and Dentostomella kuntzi (C and D). 具, Larvae; $\square$, males; $\mathbf{0}$, females.

However, spirurid eggs were identified in 24 mice $(39.3 \%)$, sufficient for more detailed analysis. The frequency distribution is shown in fig. 8, and prevalence by site of capture is summarized in table 4 . The statistical analyses were again confined to the three wadis which yielded multiple captures of mice. Log-linear analysis of the prevalence of spirurid nematodes by maximum likelihood techniques revealed that three independent interactions explained the data: age $\times$ site, site $\times$ infection and age $\times$ infection (likelihood ration $\chi^{2}=5.091$, dof $=14$, $P=0.985$ ). The age $\times$ site interaction arose because juvenile mice were mainly from Wadi Tofaha. The age $\times$ infection interaction arose because the 24 positive samples all came from adult mice. The site $\times$ infection interaction indicated that the differences in prevalence between the wadis (table 4) were significant.

Quantitative analysis was again by a multifactorial analysis of variance for these three sites, taking age, sex and body weight into account and this revealed a significant main effect of site on EPM $\left(F_{2,53}=3.38, P=\right.$ 0.042 ), with egg counts lowest in Wadi Tofaha, and highest in Wadi Abu Seylah (fig. 9). No significant effect of host age, weight or sex emerged from this analysis.

\section{Discussion}

Although the helminth parasites of Acomys spp. from Egypt have been studied previously, most published reports are taxonomic or species lists from surveys (Myers et al., 1962; Kuntz \& Myers, 1968; Ashour, 1980). Some give the prevalence of infection (Greenberg, 1969; Wertheim \& Greenberg, 1970) in Acomys spp. in relation to habitat type but, to our knowledge, none provide detailed quantitative information on helminth component community structures, range of variation in infracommunity structures nor probe the underlying ecology of the hostparasite systems involved in depth. Our quantitative analyses of parasite burdens, and of faecal egg counts as measures of prevalence and abundance of adult spirurid nematodes, therefore build on the earlier studies by Wertheim \& Greenberg (1970), making novel contributions to the understanding of the ecology of the helminths 


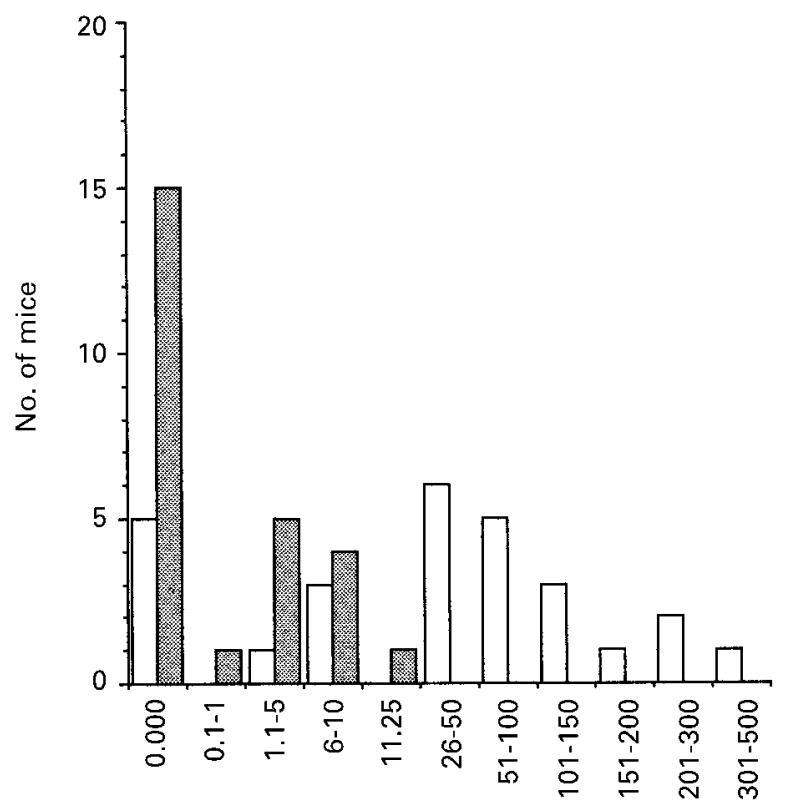

Weight categories in $\mathrm{mg}$

Fig. 6. Frequency distribution of the total worm biomass of spirurid nematodes (white columns) and Dentostomella kuntzi (grey columns) in the autopsied animals $(n=27)$.

of A. cahirinus dimidiatus inhabiting the harsh, fragile environment in the mountains of the Sinai peninsula.

All of the helminths recovered from the autopsied animals have been previously recorded from Acomys spp. in the Sinai (Wertheim \& Greenberg, 1970) and the Middle East (Greenberg, 1969; Myers, 1954, 1961; Myers et al., 1962; Kuntz \& Myers, 1968). Protospirura muricola has a very wide host, ecological and geographical range, having been recorded from many different rodent species (Baylis, 1928) including the Zambian mole rat (Scharff et al., 1997), commensal rodents (Tubangui, 1931; Baylis, 1928) and even primates (Perodicticus potto, Baylis, 1928; Cebus capucinus, Foster \& Johnson, 1938, 1939). Mastophorus muris shows a global distribution in rodents (Bangs, 1985) and is known to occur in spiny mice in Egypt (Ashour, 1980). Our specimens of Syphacia corresponded to the brief description given by Greenberg (1969) and those of $A$. africana clearly belonged to the subgenus Pseudoaspiculuris Akhtar, 1955. The six species we identified constitute only a fraction of the total helminth fauna (17 species) reported from $A$. dimidiatus sampled right across the Sinai peninsula (Wertheim \& Greenberg, 1970) but our sample was more limited and it is well recognized that parasite species richness in a given host community increases with sampling effort (Walther et al., 1995). Moreover, although Wertheim \& Greenberg (1970) sampled in the region of St Katherine, their analysis was based on the pooled data from all sites across the Sinai, and it may be that the helminth species richness at St Katherine is more limited than in the Sinai as a whole.

Perhaps the most interesting aspect of our findings was the marked dominance of the helminth component community of $A$. cahirinus dimidiatus by the spirurid

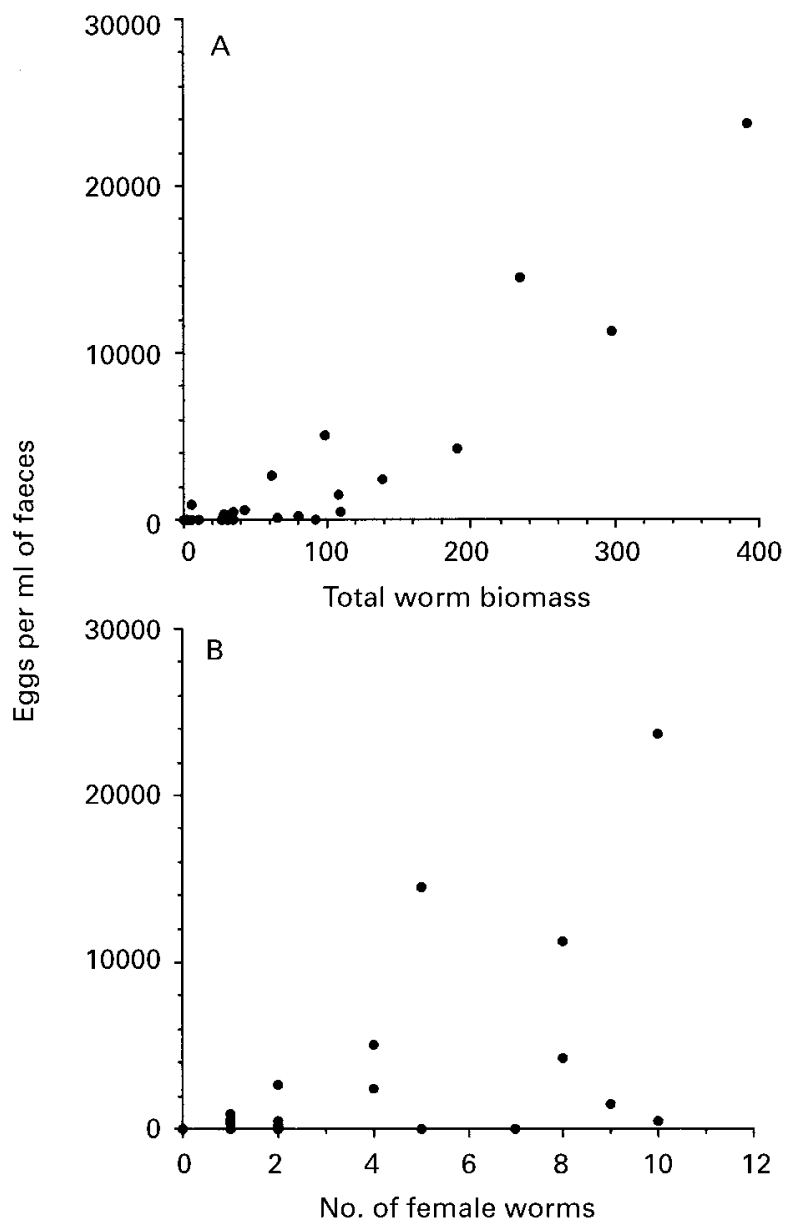

Fig. 7. Relationship between the concentration of eggs per $\mathrm{ml}$ of faeces and (A) total spirurid biomass and (B) the number of spirurid females recovered.

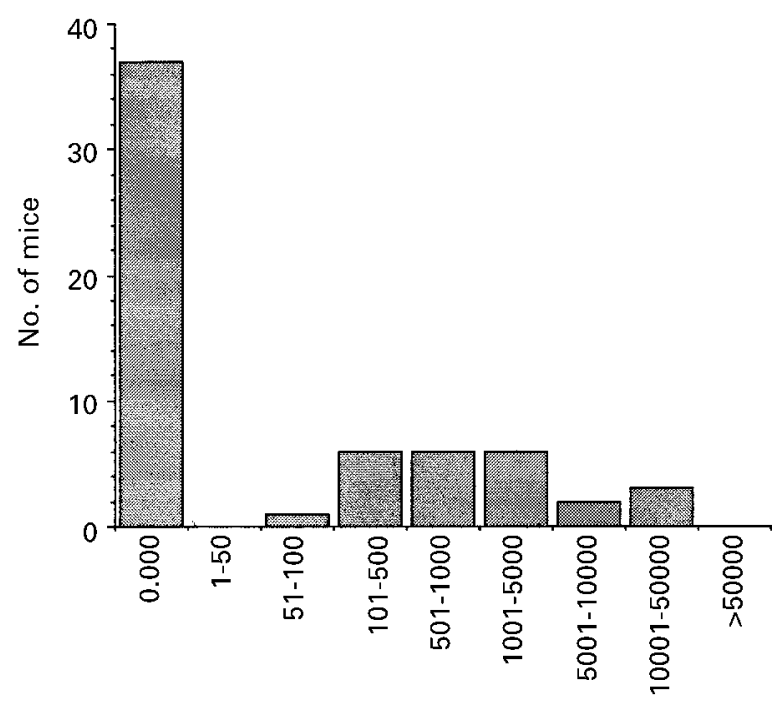

Categories corresponding to eggs per $\mathrm{ml}$ of faeces

Fig. 8. Frequency distribution of spirurid faecal egg counts $(k=$ $0.228 \pm 0.063, \chi^{2}=0.29$, dof $\left.=2, P=0.867\right)$. 


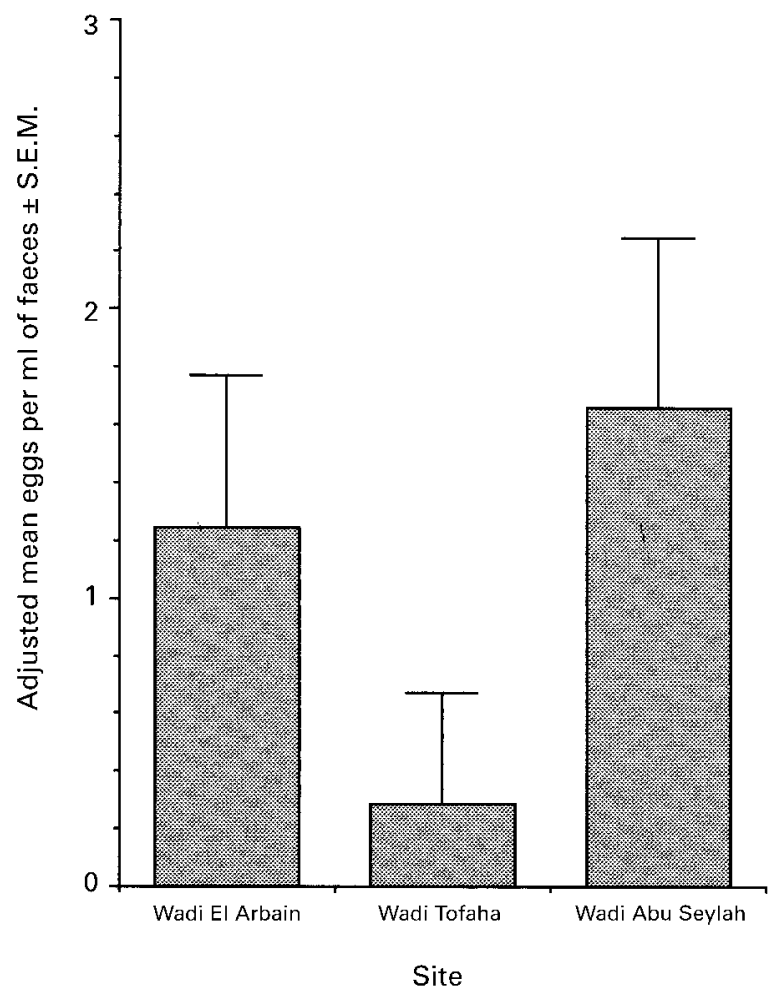

Fig. 9. Variation in spirurid faecal egg counts of mice captured from different wadis. The figure shows the adjusted means as fitted by a 3-way ANOVA (site + sex + age) with weight as a covariate on faecal egg counts $\left(\log _{10}(x+1)\right.$ transformed). For full statistical analysis see text.

nematodes (85.2\% prevalence), and particularly by $P$. muricola ( $74.1 \%$ prevalence). Earlier studies found an overall prevalence with P. muricola of only $19 \%$ and $M$. muris $5 \%$, in a sample of six species of rodents from the whole of the Sinai (Wertheim \& Greenberg 1970). However, these authors also detected a higher prevalence among A. dimidiatus from 'artificial habitats' (56.9 and 9.3\%, respectively) compared with arid regions (6.1 and 6.1\%, respectively). For the most part, our quantitative analysis of worm burdens did not distinguish between these two species because the two genera are very similar to each other and there is some confusion in the literature (Chitwood, 1938; Chabaud, 1975; Ashour, 1980; Scharff et al., 1993). Protospirura muricola and M. muris have very similar life cycles and host-parasite relationships but exploit different hosts. The developmental cycle of $P$. muricola has been described from limited experimental infections of rodents such as Praomys jacksoni, Hybomys univittatus and Thamnomys spp. (Quentin, 1969), laboratory rats and black-handed spider monkeys (Ateles geoffroyi) (Campos \& Vargas, 1978) and from captive white-faced monkeys, Cebus capucinus (Foster \& Johnson, 1939). That of $M$. muris has been reported from murid rodents (Apodemus sylvaticus, Mus musculus and Calomys callosus) (Quentin, 1970) and from laboratory rats (Shogaki et al., 1972). Quentin (1969) found that P. muricola had a prepatent period of 40 days although the prepatent period of the related species Mastophorus columbiana (previously, Protospirura columbiana, Chitwood, 1938) is about 2-3 months in duration (Cram, 1926) whilst that of M. muris is only about 28 days (Quentin, 1970). Scarff et al. (1997) list cockroaches, fleas and scarabeid beetles as the intermediate hosts of P. muricola. Foster \& Johnson (1939) found that only one species of cockroach, Leucophaea maderae, harboured larvae and this was largely confirmed by Campos \& Vargas (1977), however, Quentin (1969) reported earwigs (Dermaptera) as suitable hosts. Cram's (1926) attempts to infect cockroaches with M. columbiana suggests that some 5-6 weeks of development are necessary to reach infectivity in the intermediate host, although Quentin (1969) reported encysted third stage larvae of $P$. muricola in earwigs within 23 days of infection, and those of M. muris in locusts (Locusta migratoria), earwigs (Labidura riparia) and cockroaches (Periplaneta americana) within 4 weeks (Quentin, 1970), while Dyer \& Olsen (1967) found that Mastophorus numidica reached infectivity in insect hosts only after 38 days.

The comparatively long period of development in the intermediate host and the long prepatent periods in definitive hosts, imply that Mastophorus and Protospirura are long-lived genera (Kirschenblatt, 1938; Rausch \& Tiner, 1949), investing initially in growth and then a long period of fecundity. Our finding that only adult mice carried fecund worms and harboured a wide range of worm sizes are consistent with the idea that worm burdens accumulate in the stomachs of susceptible hosts over prolonged periods of time. Such a strategy would suit the environment in the Sinai, where insect life is highly seasonal and dependent on narrow windows when temperatures are not excessive and water is available. In this context Kirschenblatt (1938) concluded that the intensity of infection was not season-dependent although subsequently Grundman (1957) reported seasonal prevalence of $P$. numidica in various desert rodents in Utah, relating this to the seasonal abundance of insect intermediate hosts. Our expedition was limited to a two week period in late May-early June, and it is quite clear from the wide range of worm sizes that transmission had been occurring, probably for several months, preceding our sampling period. In fact, May-June are the last months when some rain is expected in the region following the wet season in December to February.

It is possible that worm burdens accumulate to levels which may exert some metabolic cost to the host. In one mouse we found $392.2 \mathrm{mg}$ of biomass from 17 worms representing $0.87 \%$ of the body weight of the host. Four other animals also had over $100 \mathrm{mg}$ of parasite burden. In these hosts the knot of stomach worms occupied a significant proportion of the volume of the stomach, and it will be interesting to determine whether such heavy worm burdens have consequences for appetite, frequency of feeding and efficiency of the digestive processes. However, we never found worms outside the stomach, as reported by Foster \& Johnson (1939) who, in their heavily infected monkeys, observed worms both more anteriorly and more distally in the intestine, as well as throughout all the visceral organs.

Although Acomys spp. are the main hosts of D. kuntzi (Myers, 1961) incidental infections have also been recorded from Arvicanthis niloticus (Nile kusu grass rat), Rattus 
rattus (Ashour \& Lewis, 1982) and Mus musculus (Myers et al., 1962). In common with other oxyuroids, this species is probably transmitted directly, but if it were to be transmitted by host contact as in murine pinworms we might have expected to see a higher focal prevalence. In fact worm burdens were low (range 1-12 worms) suggesting that the eggs of this species are liberated in host faeces and acquired during foraging. Moreover, since very few eggs were observed in the faecal samples even when female worms were present, it is conceivable that egg production is discontinuous, perhaps following an intermittent circadian or even longer-term rhythm, as in S. muris and A. tetraptera (Phillipson, 1974; Lewis \& D'Silva, 1980).

With respect to our second objective, on several criteria mice living in Wadi Abu Seylah were more heavily parasitized than those in other sites. Thus, helminth species richness, mean nematode abundance, the prevalence and abundance of spirurids (faecal egg counts) and D. kuntzi were all higher than elsewhere. Wadi Tofaha was similar to Wadi Abu Seylah in terms of mean helminth species richness, intermediate with respect to nematode abundance, but quite clearly the poorest on the basis of spirurid faecal egg counts. These differences between the wadis may reflect the relative abundance of intermediate hosts and possibly, host intrinsic factors such as genetically determined differences in resistance to parasitic helminths. The underlying mechanisms are intriguing and will hopefully be clarified by our continuing studies in the region.

For intestinal helminths of humans and domestic animals faecal egg counts (FEC) are the only non-invasive technique widely used for quantifying infections. However, FEC are fraught with problems and their accuracy has often been questioned (Keymer \& Slater, 1987) because release of eggs may show circadian and longer-term rhythms, the techniques themselves show wide intrasample variability and only infections with patent female worms can be detected. Alternatives, immunological assays such as ELISA for detecting circulating or faecal antigens, require the necessary specific reagents (Johnson et al., 1996), have only been refined for a few species and were not available for the parasites in this study. Faecal egg counts were therefore the only feasible non-invasive technique available, and this was an issue of paramount importance because this study, and the associated longerterm programme, was based in a fragile environment of immense conservation value. In the event, only one of the helminth taxa showed promise for detection via FEC, quantitative egg counts strongly predicting spirurid worm biomass. This encouraged us to believe that comparative studies of the spirurid burdens among the different species of rodents inhabiting the wadi systems, and in relation to host community structure, would be possible in the future without need for animals to be culled. Indeed, spirurid FEC revealed a significant difference between sites of capture (in contrast to spirurid abundance as detected by autopsy) but the relative importance of the wadis was different to that identified for nematode abundance. In agreement with spirurid autopsy data, but contrasting with mean helminth species richness and nematode abundance, spirurid faecal egg counts did not show a host age effect. On the basis of these results we conclude that use of FEC as a non-invasive method of quantifying parasite burdens showed some promise but further refinement is still necessary.

Finally, this paper has reported for the first time, quantitative worm burden data on the helminths infecting A. cahirinus dimidiatus from the mountain region of the Sinai. The dominance of spirurid nematodes in this host population is an interesting phenomenon. Because of the size of these parasites and their likely metabolic cost, we expect host fitness to be affected and, in consequence, these parasites may play a significant role in determining host life history strategy. How life histories vary in relation to parasite burdens and the specific hazards presented by the contrasting environments in disparate wadis remains to be elucidated.

\section{Acknowledgements}

We are grateful to the staff of the Environmental Research Centre of Suez Canal University for their hospitality and friendship and to Dr John Granger, Manager of PAMU, for permission to sample rodents in the St Katherine's Protectorate. We thank Moustafa El Naggar for guidance on optimal trapping sites locally, Rasheed for his skills in deploying traps to best effect and Hussein Saleh, our Bedouin guide for taking us to Wadi Gebal. We acknowledge the advice given by Dr D.I. Gibson and E. Harris with respect to the identity of some of the helminths and Professor J. Lewis for access to the invaluable thesis of $\mathrm{Dr} \mathrm{A}$. Ashour. The University of Nottingham provided travel funds for this project, Suez Canal University transportation and field support and the British Council, through their LINK funding, facilitated collaboration between Nottingham and Egyptian research groups.

\section{References}

Abu-Madi, M.A., Behnke, J.M., Lewis, J.W. \& Gilbert, F.S. (1998) Descriptive epidemiology of Heligmosomoides polygyrus in Apodemus sylvaticus from three contrasting habitats in south-east England. Journal of Helminthology 72, 93-100.

Ashour, A.A. (1980) Ultrastructural and other studies on intestinal nematodes of small mammals from Egypt. PhD thesis, Ain Shams University, Cairo Egypt.

Ashour, A.A. \& Lewis, J.W. (1982) The morphology of Dentostomella kuntzi (Nematoda: Oxyuroidea) from Egyptian rodents. Journal of Helminthology 56, 159-168.

Bangs, E.E. (1985) Occurrence of the nematode Protospirura muris in Alaskan Northern red-backed voles, Clethrionomys rutilus. Canadian Field Naturalist 99, 386-388.

Baylis, H.A. (1928) On a collection of nematodes from Nigerian mammals (chiefly rodents). Parasitology 20, 280-304.

Boggs, J.F., McMurray, S.T., Leslie, D.M. Jr., Engle, D.M. \& Lochmiller, R.L. (1991) Influence of habitat modification on the community of gastrointestinal helminths of cotton rats. Journal of Wildlife Diseases 27, 584-593.

Campos, M.Q. \& Vargas, M.V. (1977) Biologia de Protospirura muricola Gedoelst, 1916 y Mastophorus muris (Gmelin, 1790) (Nematoda: Spiruridae), en Costa Rica. I. Huespedes intermediarios. Revista de Biologia Tropical 25, 191-207. 
Campos, M.Q. \& Vargas, M.V. (1978) Biologia de Protospirura muricola Gedoelst, 1916 y Mastophorus muris (Gmelin, 1790) (Nematoda: Spiruridae), en Costa Rica. II. Huespedes definitivos. Revista de Biologia Tropical 26, 199-211.

Chabaud, A.G. (1975) Keys to the genera of the Order Spirurida Part 2. Spiruroidea, Habronematoidea and Acuarioidea. in Anderson, R.C., Chaubaud, A.G. \& Willmott, S.M. (Eds) CIH Keys to the nematode parasites of vertebrates. Farnham, UK, Commonwealth Agricultural Bureaux.

Chitwood, B.G. (1938) The status of Protospirura vs Mastophorus with consideration of the species of these genera. Livro Jubilar do Professor Lauro Travassos, Rio de Janeiro, pp. 115-118.

Cram, E.B. (1926) A new nematode from the rat, and its life history. Proceedings of the US National Museum 68, 1-7.

Dyer, W.G. \& Olsen, O.W. (1967) Biology of Mastophorus numidica (Seurat 1914) Read and Millemann, 1953 (Nematoda: Spiruridae) with description of juvenile stages. Proceedings of the Helminthological Society of Washington 34, 98-103.

Elliott, J.M. (1977) Some methods for the statistical analysis of samples of benthic invertebrates. Cumbria, UK, Freshwater Biological Association.

Erhardova-Kotrla, B. \& Daniel, M. (1970) Parasitic worms of small mammals from the region of the mountain regions of the Eastern Hindu Kush. Folia Parasitologica 17, 201216.

Foster, A.O. \& Johnson, C.M. (1938) Protospirurosis, a new nematode disease of captive monkeys. Journal of Parasitology 24, 32.

Foster, A.O. \& Johnson, C.M. (1939) A preliminary note on the identity, life cycle and pathogenicity of an important nematode parasite of captive monkeys. American Journal of Tropical Medicine 31, 265-277.

Gilbert, F., Willmer, P., Semida, F., Ghazoul, J. \& Zalat, S. (1996) Spatial variation in selection in a plant-pollinator system in the wadis of Sinai, Egypt. Oecologia 108, 479487.

Greenberg, Z. (1969) Helminths of mammals and birds of Israel I. Helminths of Acomys spp. (Rodentia, Murinae). Israel Journal of Zoology 18, 25-38.

Grundman, A.W. (1957) Nematode parasites of mammals of the Great Salt Lake Desert of Utah. Journal of Parasitology 43, 105-112.

Haukisalmi, V., Henttonen, H. \& Tenora, F. (1988) Population dynamics of common and rare helminths in cyclic vole populations. Journal of Animal Ecology 57, 807-825.

Hobbs, J.J. (1995) Mount Sinai. Austin, Texas, University of Texas Press.

Johnson, M.J., Behnke, J.M. \& Coles, G.C. (1996) Detection of gastrointestinal nematodes by a coproantigen capture ELISA. Research in Veterinary Science 60, 7-12.

Keymer, A.E. \& Slater, A.F.G. (1987) Helminth fecundity: density dependence or statistical illusion? Parasitology Today 3, 56-58.

Kirschenblatt, J.D. (1938) Die Gesetzmaessigkeiten der Dynamik der Parasitenfauna bei den maeuseaehnlichen Nagetieren (Muriden) in Transkaukasien. Dissertation, University of Leningrad, pp. 5-92 (in Russian with German summary).

Kisielewska, K. (1970) Ecological organization of intestinal helminth groupings in Clethrionomys glareolus (Schreb.)
(Rodentia). V. Some questions concerning helminth groupings in the host individuals. Acta Parasitologica Polonica 17, 197-208.

Kuntz, R.E. \& Myers, B.J. (1968) Helminths of vertebrates and leeches taken by the U.S. naval medical mission to Yemen, Southwest Arabia. Canadian Journal of Zoology 46, 1071-1075.

Lewis, J.W. \& D'Silva, J. (1980) Rhythmic egg deposition by the oxyurid nematode Syphacia muris in the rat. Journal of Zoology 191, 429-433.

Montgomery, S.S.J. \& Montgomery, W.I. (1990) Structure, stability and species interactions in helminth communities of wood mice Apodemus sylvaticus. International Journal for Parasitology 20, 225-242.

Murphy, M.F. (1952) Ecology and helminths of the Osage wood rat, Neotoma floridana osagensis, including the description of Longistriata neotoma n.sp. (Trichostrongylidae). American Midland Naturalist 48, 204-218.

Myers, B.J. (1954) Helminth parasites of reptiles, birds, and mammals of Egypt. I. Streptopharagus kuntzi sp. nov., from rodents, with a review of the genus. Canadian Journal of Zoology 32, 366-374.

Myers, B.J. (1961) Helminth parasites of reptiles, birds and mammals of Egypt. VI. Dentostomella kuntzi n.sp. a new oxyurid nematode from Acomys spp. Canadian Journal of Zoology 39, 55-57.

Myers, B.J., Kuntz, R.E. \& Wells, W.H. (1962) Helminth parasites of reptiles, birds, and mammals in Egypt. VII. Check list of nematodes collected from 1948 to 1955. Canadian Journal of Zoology 40, 531-538.

Ow-Yang, C.K. (1971) Studies on the nematode parasites of Malaysian rodents. I. The Rhabdiasidea, Trichuridea and Oxyuridea. Journal of Helminthology 45, 93-109.

Phillipson, R.F. (1974) Intermittent egg release by Aspiculuris tetraptera in mice. Parasitology 69, 207-213.

Quentin, J.C. (1966) Oxyures de Muridae africains. Annales de Parasitologie 41, 443-452.

Quentin, J.C. (1969) Cycle biologique de Protospirura muricola Gedoelst 1916 (Nematoda: Spiruridae). Annales de Parasitologie 44, 485-504.

Quentin, J.C. (1970) Morphogenese larvaire du spiruride Mastophorus muris (Gmelin, 1790). Annales de Parasitologie 45, 839-855.

Rausch, R. \& Tiner, J.D. (1949) Studies on the parasitic helminths of the North Central States. II. Helminths of voles (Microtus spp.). Preliminary report. American Midland Naturalist 41, 665-694.

Scharff, A., Barus, V., Tenora, F. \& Burda, H. (1993) Head morphology of Protospirura muricola (Nematoda: Spiruridae) and its taxonomic importance. Helminthologia 30, 163-167.

Scharff, A., Burda, H., Tenora, F., Kawalika, M. \& Barus, V. (1997) Parasites in social subterranean Zambian molerats (Cryptomys spp., Bathyergidae, Rodentia). Journal of Zoology 241, 571-577.

Shogaki, Y., Mizuno, S. \& Itoh, H. (1972) On Protospirura muris (Gmelin) a parasitic nematode of the brown rat in Nagoya City. Japanese Journal of Parasitology 21, 28-38.

Tubangui, M.A. (1931) Worm parasites of the brown rat (Mus norvegicus) in the Philippine islands, with special reference to those forms that may be transmitted to human beings. The Philippine Journal of Science 46, 537-589.

Walther, B.A., Cotgreave, P., Price, R.D., Gregory, R.D. \& 
Clayton, D.H. (1995) Sampling effort and parasite species richness. Parasitology Today 11, 306-310.

Wertheim, G. (1963) Helminth parasites of the rat Rattus norvegicus from Haifa and Tel-Aviv. Bulletin of the Research Council of Israel 10E, 125-129.

Wertheim, G. \& Greenberg, Z. (1970) Notes on helminth parasites of myomorph rodents from southern Sinai. Journal of Helminthology 44, 243-252.

Willmer, P., Gilbert, F., Ghazoul, J., Zalat, S. \& Semida, F.
(1994) A novel form of territoriality: daily paternal investment in an anthrophorid bee. Animal Behaviour 48, 535549.

Zalat, S. \& Gilbert, F. (1998) A walk in Sinai: St Katherine to Al Galt Al Azraq (The Blue Pool). Cairo, Egypt, El Haramen Press.

(Accepted 21 July 1999)

(C) CAB International, 2000 